\title{
WARS AND HEROES: THE ROMANTIC REPRESENTATION OF SPAIN IN DON JUAN; OR THE BATTLE OF TOLOSA (1816)
}

\author{
Sara Medina Calzada \\ University of Valladolid \\ smedina@fyl.uva.es
}

\begin{abstract}
This paper examines Don Juan; or the Battle of Tolosa, an anonymous poem published in London in 1816. This metrical tale set in medieval Iberia at the time of the so-called reconquista recreates the Battle of Las Navas de Tolosa (1212), in which the Muslim forces were defeated by a Christian coalition near Sierra Morena. The poet clearly sides with the Christians, who are depicted as brave warriors struggling to recover their land and their freedom. The emphasis on their patriotic heroism against foreign usurpation creates an implicit analogy between the medieval battle and the recent events of the Peninsular War (18081814). The representation of Spain as a land of war and romance echoes the Romantic figurations of this country appearing in British print culture in the early nineteenth century.
\end{abstract}

Keywords: Don Juan; or the Battle of Tolosa, representations of Spain, British Romanticism, Peninsular War, medievalism, Muslim Iberia. 


\title{
GUERRAS Y HÉROES: LA REPRESENTACIÓN ROMÁNTICA DE ESPAÑA EN DON JUAN; OR THE BATTLE OF TOLOSA (1816)
}

\begin{abstract}
RESUMEN. Este trabajo analiza Don Juan; or the Battle of Tolosa, un poema anónimo publicado en Londres en 1816 cuya acción se sitúa en la España de la reconquista y, más concretamente, en la Batalla de las Navas de Tolosa (1212), en la que una coalición de los reinos cristianos peninsulares derrotó a las tropas musulmanas cerca de Sierra Morena. El poeta se posiciona a favor de los cristianos, a los que describe como una nación de guerreros que tratan de recuperar su tierra y su libertad. El interés del autor por destacar el heroísmo y el patriotismo de los cristianos frente a los que considera invasores extranjeros establece una analogía implicita con la Guerra de la Independencia. Se trata de una representación romántica de España que incide en lo belicoso y lo caballeresco, en línea con la imagen del país presente en la literatura británica de comienzos del XIX.
\end{abstract}

Palabras clave: Don Juan; or the Battle of Tolosa, representaciones de España, Romanticismo británico, Guerra de la Independencia, medievalismo, Al-Andalus.

Received 6 March 2017

Revised version accepted 3 July 2017

\section{INTRODUCTION}

The Peninsular War (1808-1814) was a turning point in the course of the complex-and frequently problematic-Anglo-Spanish political and diplomatic relations. At this time, after centuries of declared enmity, Spain and Britain became allies in their fight against a common enemy: Napoleon Bonaparte. The involvement of British forces in the Peninsular campaigns aroused an unprecedented interest and enthusiastic support for the Spanish cause among the British public opinion, a phenomenon that is well reflected in Romantic print culture. The events taking place in the Iberian Peninsula together with the Romantic reappraisal and fascination with Spain in Europe gave way to new portrayals of the Spanish culture and national identity, which gradually relegated the stereotypes of the Spanish Black Legend and reinterpreted the backwardness of the country as a relic of its chivalric and romantic spirit. These British Romantic images of Spain, especially as presented in metrical tales, are thoroughly examined by Saglia in his ground-breaking and highly influential Poetic Castles in Spain: British Romanticism and Figurations of Iberia (2000). His study is complemented by other scholarly approaches to the examination of British fictional representations of Spain, such as those by Valladares (2015), who explores English theatre during the Peninsular War, or Almeida-Beveridge 
(2010), who is the editor of a volume devoted to the analysis of the Romantic Anglo-Hispanic imaginary. Furthermore, an English/Spanish bilingual anthology of the English poetry of the Peninsular War has been edited by Coletes Blanco and Laspra Rodríguez (2013). All these studies reveal that Spain attracted the attention not only of British canonical figures, but also of minor and forgotten authors who found their inspiration in episodes of Spanish history, elements of its culture, and contemporary events. One of these literary works consigned to oblivion is Don Juan; or the Battle of Tolosa (1816). It is an anonymous poem published in the aftermath of the Peninsular War which reconstructs the Battle of Las Navas de Tolosa (1212), a momentous episode in the medieval wars between the Christian and the Muslim kingdoms of the Iberian Peninsula that have traditionally been known as the reconquista. This three-canto metrical tale, which has been entirely disregarded by scholars, participates in the existing vogue for Spanish themes in Romantic print culture and follows some of the prevailing trends in the British Romantic depictions of Spain. The focus of my analysis is placed on the poet's representation of Spain and the Spanish people through the portrayal of the conflict between the Christians and the Moors and its possible associations with contemporary events.

\section{THE AUTHORSHIP OF DON JUAN; OR THE BATTLE OF TOLOSA}

Little is known about the circumstances of the publication of Don Juan; or the Battle of Tolosa, apart from the fact that it was published anonymously in London in 1816. Given the absence of reviews and references in the literary press of the time, the poem must not have made a great impression on British critics and readers. The book has never been edited again and, nowadays, it can be regarded as a mere bibliographic rarity. Moreover, the identity of its author remains an unresolved question, even if a careful analysis of the two copies kept at the British Library, to which I had access in the course of my investigation, provide a few suggestive but inconclusive clues on the authorship of the poem. One of these two copies is bound with another anonymous metrical tale entitled De Mowbray, which was published in 1815. The publisher and the printer of both Don Juan; or the Battle of Tolosa and De Mowbray were James Harper (Fleet Street, London) and T. Davidson (Blackfriars, London), respectively. In addition, the two poems have the same structure: they are divided in three cantos, which are followed by a series of notes and some brief poems that conclude the volumes. The subject matter of the two works is not dissimilar either. The same as Don Juan; or the Battle of Tolosa, De Mowbray is also set in the Middle Ages and recreates the religious wars between Islam and Christianity, although in this case the author moves the action back to the Crusades at the time of Richard I. Furthermore, there are significant 
stylistic similarities between the two poems, so it seems reasonable to suggest that they might have been written by the same person. However, De Mowbray contains no further hints about its authorship.

On the other hand, James Harper, the publisher of both Don Juan; or the Battle of Tolosa and De Mowbray, produced another work related to Spanish themes in 1815. It is The Inquisition, or, Tale of Varez, written by Richard N. Kelly, a lieutenant of the Royal Navy. According to the preface, in the recent years he had been "placed in a situation that enabled him to witness the extraordinary efforts made by the Spanish patriots to restore their Monarch to the throne" (iii-iv), thus implying that he participated in the Peninsular War. The reading of The Inquisition, or, Tale of Varez reveals remarkable similarities between Kelly's poem and the anonymous Don Juan; or the Battle of Tolosa in terms of diction. Besides, both of them are metrical tales written in heroic couplets and, most importantly, they depict the Spaniards as a heroic people fighting for their freedom. Nevertheless, I have not been able to trace any further link between Kelly and either Don Juan; or the Battle of Tolosa or De Mowbray-assuming that both of them were composed by the same person. As I explain below (section 4), the heroism of the Spanish people is frequently highlighted in the Romantic image of Spain portrayed by British writers during the Peninsular War and its aftermath. However, in The Inquisition, or, the Tale of Varez, the brave efforts of the Spanish patriots and the decisive intervention of the British troops are presented as futile actions insomuch as absolutism was re-established in Spain with the restoration of Ferdinand VII to the throne in 1814. Kelly's poem evokes the Black Legend by narrating the fictional story of Alonzo, a Spanish freedom-fighter who is sentenced to death by the Inquisition after being erroneously accused of supporting Francisco Espoz y Mina's uprising against Ferdinand VII. The poem contains a bitter criticism to Spanish rulers which is totally absent in Don Juan; or the Battle of Tolosa. Considering all these aspects, Kelly may have authored Don Juan; or the Battle of Tolosa too, but the truth is that the above-discussed connections between the poems cannot be considered conclusive evidence for his authorship.

\section{A TALE OF THE RECONQUISTA}

Don Juan; or the Battle of Tolosa combines both history and romance. The action starts in Seville on a lovely summer night, when Inez leaves her castle near the banks of the Guadalquivir to elope with Don Juan, her lover:

Lady, awake! It is a lovely night

Holy in silence, and in splendour bright:

The stars are trembling o'er thy myrtle bowr's, 
The moon-beams play upon thy father's tow'rs

The trees are sighing in the summer gale,

And stillness slumbers in the distant vale;

The nightingales alone those slumbers break,

And warbling woo thee, lady, to awake. (1-2)

The first lines of the poem certainly evoke the Don Juan legend, and this must have been the reason why it is classified as "spurious cantos and imitations" of Byron in the British Library catalogue. Since the poem was published in 1816, it cannot be an imitation of Byron's Don Juan, whose first cantos did not appear until 1819. Such impossibility is pointed out by Weinstein (1959: 199) and Singer (1965: 35), who, in turn, suggest that Byron may have drawn inspiration from Don Juan; or the Battle of Tolosa for some of the episodes of his epic. Nevertheless, Weinstein's and Singer's identical summaries of the anonymous poem reveal a superficial and distorted knowledge of its plot. As a matter of fact, it is extremely unlikely that Byron could have used it as a source of his Don Juan because the only connections between Don Juan; or the Battle of Tolosa, Byron's poem, and the Don Juan legend are a couple of proper names. The reader soon discovers that the knight with whom Inez has just fled is not Don Juan, but the Moor Hassan, who is disguised as Don Juan in order to deceive and abduct her. The purpose of Hassan's scheme is to take revenge on his Christian enemies: the aforementioned Don Juan and Don Rodrigo. The latter, who is both Inez's father and the Bishop of Toledo, corresponds to the historical character Rodrigo Jiménez de Rada (1170-1247), the Archbishop of Toledo and counsellor of Sancho VII of Navarre, Alphonso VIII, and Ferdinand III of Castile. Therefore, the poem is not a narration of the adventures and misadventures of a libertine, but a tale of the reconquista, which is set in the Middle Ages and deals with the wars fought between the Christians and the Moors so as to take control of the Iberian Peninsula. The story is set at a very precise historical event: the momentous Battle of Tolosa (1212), in which the Christian troops defeated the Muslim forces near Sierra Morena.

The kidnapping of Inez occurs on the eve of this battle. Hassan takes her to his castle, where the real Don Juan is imprisoned too. Don Juan and Don Rodrigo had been captured by the Moors in their last battle, but Rodrigo managed to escape and joined the army of Alphonso VIII of Castile. Hassan informs Inez of Don Juan's confinement and threatens to kill him unless she consents to satisfy his lustful desires - a proposition that the virtuous Inez firmly rejects. At this point of the story, Hassan's servants tell him that a general of the Miramolin ${ }^{1}$

\footnotetext{
1 The Miramamolin_called Miramolin in the poem-is a title given to the caliphs. In this case, given the setting of the story, it refers to Muhammad an-Nasir (1181-1213), the fourth caliph of the Almohad dynasty.
} 
is waiting for him and urge him to prepare for the great battle that would be fought on the following day. Hassan immediately departs, leaving Don Juan and Inez in his castle. They are liberated by Mahmoud, one of Hassan's servants, who takes Inez safely to the Christian frontier and gives Don Juan the sword of King Pelayo, the Asturian nobleman who has been traditionally regarded as the first hero of the reconquista. Well equipped with Pelayo's sword, Don Juan reaches the battlefield just in time to join the Christian troops led by Alphonso VIII of Castile, Sancho VII of Navarre, and Don Rodrigo. Although the Muslim army outnumbers the Christian coalition, the former are eventually defeated. Hassan is killed by his servant Mahmoud, who is also killed by another servant. Don Juan does not only survive, but becomes a hero after killing the Miramolin with Pelayo's sword.

\footnotetext{
Pelagio's sword in Juan's vigorous grasp,

With blow terrific, cuts thro' joint and clasp -

Cleft thro' the skull, the Prince of Moslems dies,

And awful victory mounts the pealing skies:

The Moors behold their gallant leader slain,

And faint and wounded fly th' ensanguin'd plain!

Terror, shame, rage, despair, defeat, and pain,

Hover around, and urge their broken train:

In wild confusion, fast pursued, they fly -

The only care in quite peace - to die! (60)
}

Then the story has a typical happy ending: Don Juan marries Inez and, presumably, they live happily ever after.

The poem's storyline is considerably indebted to the traditional historical accounts of the Battle of Las Navas de Tolosa. The historical characters and events described in the poem are explained in a series of erudite notes included at the end of the text (67-78). Certainly, this type of notes is not uncommon in Romantic narrative poetry, and they are usually found in the poems by canonical authors like Robert Southey or Walter Scott. Although the endnotes contained in Don Juan; or the Battle of Tolosa are not as overwhelmingly numerous and detailed as those of Southey's works, they show that the anonymous author was concerned about the historical accuracy of the story and wanted to inform the readers of the events on which the fiction was based. Furthermore, these notes provide information on the author's sources: John Bigland's The History of Spain from the Earliest Period to the Close of the Year 1809 (1810: 172-177) and Tomás de Iriarte's Lecciones instructivas sobre la historia y la geografia (1794: 117-119). A passage from Iriarte's book is directly quoted in Spanish 
in the first note (70-71), which suggests that the anonymous author could read Spanish texts. Although both works basically contain brief and simplified accounts of the Battle of Las Navas de Tolosa, they are the main-and probably only-sources consulted by the poet in the composition of the text. In fact, the historical details contained in the poem and the notes can be easily identified in Bigland's and Iriarte's histories. Both Bigland and Iriarte underline the fact that the Muslim soldiers outnumbered the Christian ones, a circumstance that is also highlighted in the poem, in which the figures provided by Bigland (1810: 173) are reproduced in one of the notes (68). Moreover, both authors comment on the fact that most of the foreign crusaders who participated in the Christian coalition deserted before the battle (Iriarte 1794: 117-118; Bigland 1810: 173). This desertion is explained by the poet as follows:

But now the signal flies, and to the fight

Moves warlike Spain, 'more lovely in her might';

Small is her band; the foreign knights who came

To aid her cause, are renegades to fame! -

The German arms have sought their distant home;

And far from hence th' Italians levies roam:

The knights of France and England still remain,

To fight for victory, the cross, and Spain! (55-56)

A comparison of the preceding lines and the poem's sources reveals that the poet modifies slightly this information regarding foreign intervention. Iriarte refers to the desertion in general terms (1794: 117-118), while Bigland clarifies that most of the German and French warriors deserted, but their chiefs remained (1810: 173). They mention neither English nor Italian crusaders. In fact, modern studies of this battle do not attribute a relevant role to English forces either ${ }^{2}$ (García Fitz 2008: 218-224; Alvira Cabrer 2012: 86-111). Nonetheless, it is worth noting that one of the leaders of the foreign troops was the Archbishop of Bordeaux and that this city was the capital of Aquitaine, which was an English possession from 1154 to 1453. Strictly speaking, the crusaders from Aquitaine were vassals to the King of England and, therefore, the poet is not entirely mistaken when he remarks that "The knights of France and England still remain" (56). In any case, the author was

\footnotetext{
2 In his Chronica majora, the thirteenth-century English chronicler Matthew Paris suggested that King John had formed an alliance with the Almohad caliph Muhammad an-Nasir, and even planned to convert to Islam in the years previous to the Battle of Las Navas de Tolosa. However, modern historians reject Paris's hypothesis: King John's conversion never occurred and, if there was any attempt to obtain an-Nasir's support, this alliance should be understood as a strategy to oppose the Pope Inocence III and Alphonso VIII of Castile, both of them enemies of King John (Alvira Cabrer 2012: 90; Villegas Aristizábal 2015: 119).
} 
probably unaware of these subtleties and simply tried to magnify the role played by the English crusaders in the Christian cause in order to portray his compatriots more favourably.

In addition, the description of the battle includes other elements that the anonymous poet read in Bigland's and Iriarte's works. One of them is related to the difficulties that the Christian army had to face before the beginning of the combat. Echoing the traditional historiography, Bigland (1810: 174) narrates that the Muslim forces controlled all the passes of Sierra Morena, but the Christian troops took them by surprise as they crossed the mountains with the help of a shepherd who led them through some unknown paths. This episode is also incorporated in the poem (52-53). Moreover, Bigland's use of the term Miramolin-instead of Miramamolin - is borrowed by the poet, who presents the caliph Muhammad anNasir fighting in the battlefield with the Koran in one hand and his sabre in other hand (69), exactly as described by Bigland (1810: 175). However, the Miramamolin was not killed in the battle, so this must have been added by the poet so as to make the story more interesting and emphasize the heroic behaviour of Don Juan. On the other hand, the anonymous author follows Iriarte when explaining that the King of Navarre broke the chains that protected the Muslim lines. This episode probably never took place, but it is one of the legends that surround the battle and can be found in the works written by Spanish chroniclers and historians as well. The poem thus recreates the conflict following the conventional narrations of the Battle of Las Navas de Tolosa included in Bigland's and Iriarte's texts and introduces a few minor changes for literary purposes.

The poet's depiction of the battle is not particularly remarkable for its originality and, certainly, it is not outstanding for its objectivity either. On the contrary, the anonymous author sides with the Christians from the very first lines of the poem, and the battle is presented as a struggle between native and invading forces. In a rather anachronistic way, the Iberian Christian kingdoms are defined as Spain and their peoples are portrayed as the legitimate inhabitants of the Iberian Peninsula. By contrast, although the Muslims dominated enormous areas of the Peninsula since the early eighth century, they are considered invaders and usurpers. This implies that the author's definition of the Spanish identity excludes its Moorish past. Furthermore, the poet establishes a clear contrast between the Christians and the Moors. Whereas the Spanish Christian warriors are depicted as freedom fighters, the Moors are said to be "born to be slaves, and faithful to their chains" (25). The repressiveness of the Islamic world is stressed by the poet when he describes Hassan's servants, who are presented as "Slaves e'en in thought" and the miserable "tenants of a spacious tomb" (35). Hassan emerges as the villain of the story and is depicted as a "ferocious Moor" 
(4), a tyrant $(35,37)$, and a despot (35). The concept of Oriental despotism ${ }^{3}$ gained momentum in eighteenth-century Europe, especially in the works of enlightened philosophers like Montesquieu, but the links between despotic governments and Eastern civilizations were well rooted in Western tradition before then and can be traced back to Aristotle. Romantic authors, however, showed an ambiguous attitude towards the tyranny frequently associated with Islam, so, in the words of Sharafuddin (1996: xxi), despotism should be regarded as "a major signpost" rather than as a theme of Romantic Orientalism. The image of Moorish Iberia portrayed by the anonymous author of Don Juan; or the Battle of Tolosa perpetuates the Western notion of Oriental despotism, but, at the same time, rejects the Romantic European figurations of Spain as an Oriental nation.

In addition, by placing the story in the context of the wars between the Christian and Muslim kingdoms in the Iberian Peninsula and presenting Al-Andalus as a civilization in decline, Don Juan; or the Battle of Tolosa participates in the vogue for Spanish-Moorish Orientalism in British Romantic literature, although the poem is not entirely imbued with the sentimentalism that prevailed in the Romantic retellings of the fall of Islamic Spain. The decadence of Al-Andalus, which culminated with the fall of Granada in 1492, was a theme constantly reelaborated in Romantic literature. As examined by Saglia (1997; 2000: 254-269; 2002), the tales and legends of Granada attracted and charmed both renowned and now-forgotten British Romantic writers alike. Before Washington Irving celebrated the exotic and poetic Moorish legacy in his famous Tales of the Alhambra (1832), the decline of the Iberian Muslim kingdoms was fictionally recreated in the works of a good number British writers, including Felicia Hemans' "The Abencerrage" (1819) or Lord Porchester's The Moor (1825) as well as Thomas Rodd's The Civil Wars of Granada (1801), the English translation of Ginés Pérez de Hita's Historia de las guerras civiles de Granada (1595). Similarly, Don Juan; or the Battle of Tolosa also reveals an interest in the decline of AlAndalus, but, in this case, since the story is set in 1212, the symbol of the fall of Muslim power is not Granada, but the fortified palace-city of Medina Azahara, the capital of the Caliphate of Cordova in the tenth century. The marginal presence of Medina Azahara in British texts can by no means be comparable to the enormous popularity of the Alhambra of Granada among Romantic travellers and writers. According to one of the endnotes, the poet's knowledge of Medina Azahara is based on Bigland's History of Spain (1810: 118-122), which, as discussed above, also provided him with information regarding the Battle of Las

\footnotetext{
3 Leaving aside the highly influential analysis of Western representations of the East provided by Edward Said's Orientalism (1978), the concept of Oriental despotism has been examined and reexamined over the last decades by numerous scholars, such as Grosrichard (1998), Rubiés (2005), Curtis (2009), or Tzoref-Ashkenazi (2013), among others.
} 
Navas de Tolosa. In this endnote, the anonymous author underlines the "regal felicity" of Abd-ar-Rahman III (ca. 890-961) and the lavishness of his palace, which is compared to the "splendid and luxurious wonders of the Arabian Nights" (73-74). However, Medina Azahara was sacked and destroyed in the early eleventh century, and its ruins are presented by the poet as the vestige of the lost splendour of the reign of Abd-ar-Rahman III:

Oh! Mark the relics of her former state,

The mute, but mournful eloquence of fate! (...)

'Behold the empty glories of a King,

And all that luxury and pow'r can bring,

When Abdalrahman's bright and mighty sphere

Of fame and empire has concluded here!

The marble Zehra weeps her sov'reigns' doom,

And views at one a palace and a tomb!

While shades of pleasure flit along the walls,

The winds of heav'n are howling through her halls!

Pomp, splendour, joy! - and these, alas! are fled!

It seems the silent desert of the dead! (12-14)

The contrast between the current emptiness, shadows, and silence of Medina Azahara contrasts with its former luxury, brightness, and magnificence. The comparison of the palace with a tomb, which is later on repeated in the description of Hassan's castle and his servants (35; see above), does not only refer to the end of the Caliphate of Cordoba and its disintegration into smaller kingdoms, but also seems to anticipate the doom of Muslim Iberia: the carnage of Las Navas de Tolosa in 1212 and the eventual fall of Granada in 1492. The ruins of Medina Azahara thus represent the slow but gradual and inevitable decay of a civilization portrayed by the author as the alien and illegitimate inhabitants of a space which they had conquered and from which they were to be expelled.

\section{4. 'OH LAND OF HEROES': OF SPANISH WARRIORS AND PATRIOTS}

Although the Battle of Las Navas de Tolosa was not a popular theme in British literature, wars and conflicts were frequently chosen by British Romantic writers as the settings for their fictional representations of Spain. Whether the opponents were the Romans and the Celtiberians, the Christians and the Moors, or the Spanish patriots and the French Napoleonic troops, for centuries the Iberian Peninsula had been an arena of struggle which British Romantic authors exploited successfully in their works. As Saglia points out, "either directly or 
indirectly, the ways in which Spain was narrated by the British Romantics owed much to the general perception of this nation as a conflictive area" (2000: 19). These conflicts are frequently presented as a fight between Spanish patriots against foreign invaders, as in the last lines of Don Juan; or the Battle of Tolosa:

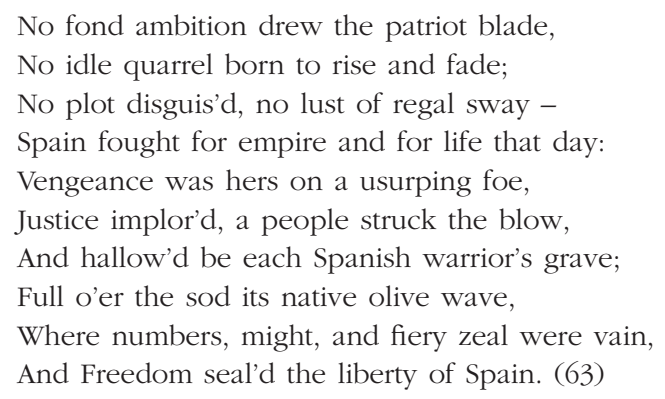

These lines refer to the warriors of the Christian coalition who defeated the Muslim forces in Las Navas de Tolosa in 1212, but, since they contain no reference to the medieval setting of the poem, they could have been perfectly applied to the Spaniards who resisted against Napoleon. In fact, the poet's insistence on the recovery of their freedom and independence implicitly connects the poem with the recent events of the Peninsular War, which is precisely known as Guerra de la Independencia in Spanish historiography. The parallelism between the anti-Napolenic campaigns and the reconquista, which obviously lies on the fact that both conflicts have been traditionally interpreted as struggles against foreign aggression, is reinforced by other elements in the poem. A connection between the Battle of Las Navas de Tolosa and the context in which the text was produced is established through the "Elegy" for the fallen in Waterloo, which is included at the end of the volume of Don Juan; or the Battle of Tolosa, just after the endnotes (79-88). As it is well known, in the Battle of Waterloo (1815), the French army, led by Napoleon himself, was defeated by the coalition under the command of the Duke of Wellington. This battle brought Napoleon's power to an end and confirmed the military supremacy of Britain, which had been already attested in their providential involvement in the Peninsular War. Therefore, with the inclusion of this "Elegy", which celebrates the British victory after an epic battle, the poet somehow connects the Napoleonic Wars with the medieval conflicts between the Christians and the Moors in the Iberian Peninsula, all of which are interpreted by the poet as struggles between patriotic freedom fighters against foreign usurpers.

Furthermore, throughout the text of Don Juan; or the Battle of Tolosa, there are other signs that evoke the events of the Peninsular War. This is the case of 
the names of the battles. Apart from the battle of 1212, there is another Battle of Tolosa in the history of Spain, which took place near the town of Tolosa (Navarre, Spain) on 25 June 1813, just four days after the Battle of Vitoria. In the battle of 1813, the Anglo-Spanish forces tried to intercept the defeated French troops in their retreat and, even though they did not succeed in their initial aim, the withdrawal of the Napoleonic army minimized the French presence in Northern Spain. Moreover, the Peninsular War featured another Battle of Tolosa: the Battle of Toulouse, which was fought on 10 April 1814 and put an end to the Peninsular War. The French city of Toulousse, which gave its name to the battle, was known in Spanish as Tolosa, so the title of the poem indirectly echoes this battle as well. In addition, the author of Don Juan; or the Battle of Tolosa refers to the Battle of Uclés, in which the sword of Pelayo was taken by the Muslim troops (45, 78). This Battle of Uclés took place in 1108 near Uclés (Cuenca, Spain), where the Christian forces led by Alphonso VI of León were crashed by the Moors. In like manner, seven centuries later and within the context of the Peninsular War, there was another Battle of Uclés which resulted in a tremendous defeat for the Spanish troops under the command of Francisco Javier Venegas. In the words of Cayuela Fernández and Gallego Palomares (2008: 184), this battle was "una verdadera catástrofe" - a real catastrophe-since thousands of Spanish soldiers were either killed or captured, and the remnants of the Spanish army had to retreat to Andalusia. The echoes of these homonymous battles contribute to trace a series of links between the past and the present which suggest that the history of Spain tends to repeat itself.

Nevertheless, the parallelism between the events in the 1808-1814 period and the reconquista was not an original contribution of the anonymous author of Don Juan; or the Battle of Tolosa. On the contrary, it was recurrently exploited in English texts since the outbreak of the Peninsular War. In particular, British Romantic writers focused their attention on the Muslim invasion of the Iberian Peninsula in 711 and the legend of Don Roderick, the last Visigothic King of Hispania. According to the traditional story, Don Roderick raped Florinda, the daughter of Don Julian, Count of Ceuta. Don Julian took revenge on Don Roderick and assisted the Moorish commanders in their invasion of the Iberian Peninsula. The presence of the Roderick theme in British Romanticism, which has been analysed by Saglia (1999; 2000: 76-115) and Valladares (2012), among others, is best reflected in Walter Scott's The Vision of Don Roderick (1811), Walter Savage Landor's Count Julian (1812), and Robert Southey's Roderick, the Last of the Goths (1814), all of them composed in the years of the Peninsular War. Apart from these three retellings, the legend of Don Roderick is also alluded in Byron's Childe Harold's Pilgrimage (I.35) and is the subject chosen by other 
minor British poets, a fact that reveals that it was a particularly fruitful theme in British Romanticism. In addition, the so-called reconquista was evoked and recreated in Spain during the Peninsular War too. As stated by Freire López (2015: 43), the parallelisms between the Moorish and the Napoleonic invasions were present in the Spanish collective imaginary since the outbreak of the 1808 conflict. In fact, Freire López explains that old Spanish plays featuring the exploits and victories of the reconquista were staged throughout the war years in order to promote the patriotism of the Spanish people (Freire López 2013: 164; 2015: 43-51). Consequently, the implicit or explicit connections between these two moments in history were recurrently established both in Britain and Spain during the war years.

Moreover, the analogy between these past and present events was not simply based on the invasions themselves, but also in the reaction of the native inhabitants of the Peninsula. The literary works about Spanish affairs published in Britain during the Peninsular War and its aftermath tend to underline the heroicness and patriotism shown by the Spanish people throughout time. Don Juan; or the Battle of Tolosa certainly emphasizes these aspects as well by displaying a catalogue of fictional, historical, and semi-legendary heroic characters. Hence, the anonymous author highlights Inez's moral strength and firm resolution to protect her virtue. Her stamina is paralleled by that of her lover, Don Juan, who is described as a brave and bold warrior as well as a proud and haughty knight. In fact, Don Juan's honour features prominently in the episodes in which he remains a prisoner in Hassan's castle. His refusal to talk to him is reproached by Hassan by saying:

\footnotetext{
No word, Don Juan? Learn then, haughty boy,

That ev'n thy pride is poison'd with alloy! -

Thy stubborn pride shall melt, as Hassan cries,

Thy love, thy lady, Inez is my prize! (26)
}

This emphasis on Don Juan's pride is connected with the stereotypical representations of Castilians and Spaniards as proud individuals who were excessively concerned about issues connected with honour and nobility. This perception spread throughout Europe in the early modern period and was perpetuated by French enlightened thinkers (Iarocci 2006: 16; Lucena Giraldo 2006: 221, 224). These ideas are evoked in the depiction of Don Juan, but the hero's dignity and self-respect are essentially praised as positive traits of his character. Similarly, the leaders of the Christian coalition are presented in a very positive light. The firm courage and desperate fearlessness shown by Alphonso VIII of Castile, Sancho VII of Navarre, and the Archbishop of Toledo, Rodrigo Jiménez de Rada, are enthusiastically celebrated in the poem: 


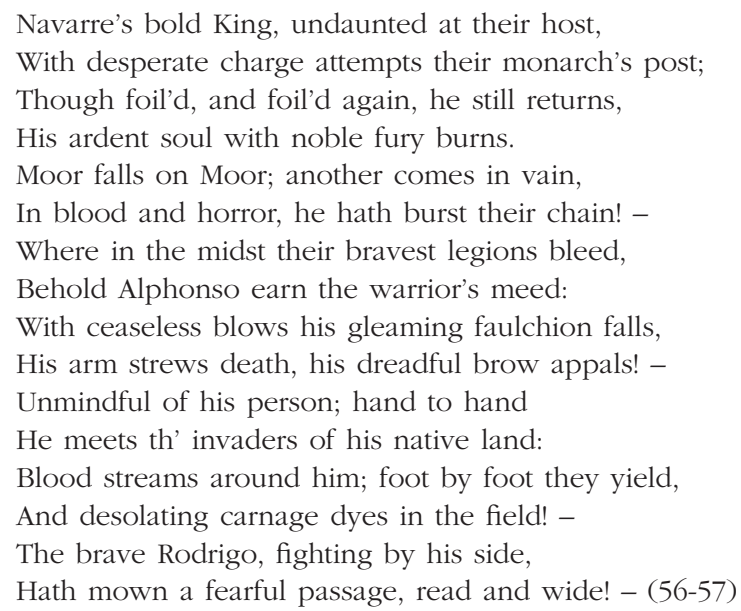

The epic nature of the battle is foregrounded to the point that it acquires a legendary dimension. The night before the battle, Don Juan has a vision in which he sees King Pelayo as if he were a celestial being or a saint. As the following excerpt shows, in the vision, the Asturian leader addresses Don Juan and gives him his sword:
A glorious vision bursts upon his sight, Celestial splendor takes the place of night; - He sees Pelagius arm'd, in gallant youth, Kneeling in pray'r before the cross of truth; A sacred halo plays around his head, And legions of the blest around him spread: Seraphs and saints, with golden harps, on high, Fill all the air with solemn harmony! A voice, at which 'tis hush'd, sublime and deep As rolling thunder, yet as soft as sleep, Bids the great King extend the sword of fame, To add new glory to a warrior's name! Pelagius rises; and to Juan's hand, With solemn air, entrusts the mighty brand! - 'For Christ, St James, and Spain, this faulchion take, Be bold in faith, remember, and awake! (39)

Therefore, Don Juan becomes the chosen one, the hero who deserves to carry the magical sword of the first King of Spain and first victorious leader of the reconquista. Pelayo's sword plays a major role in the poem and is portrayed as a sort of talisman or even relic which eventually leads the Christian troops to the victory. The poet's emphasis on the magical attributes of the sword are somehow 
reminiscent of chivalric romances and, especially, of the Arthurian tradition. This connection is explicitly established in one of the endnotes, in which the anonymous author explains who Pelayo was and compares him with King Arthur:

Pelagius was a King of Spain who gave the first blow to Moorish power, and planted the first germ of Spanish independence: he is a favourite hero with the Spaniards, and many romances have been written about him (like our own King Arthur, himself was not less renowned that his sword Excalibar [sic]): to serve the purposes of poetical interest, I have ventured to charm his sword. (77)

This comparison is a clear instance of cultural adaptation or domestication, in which the Spanish tradition is interpreted and even reformulated through its assimilation with the British legend of King Arthur. The readers of Don Juan; or the Battle of Tolosa must have been better acquainted with the Arthurian tradition than with the heroic deeds of the eighth-century Asturian King, although Pelayo was not a completely unfamiliar figure for the British reading public. As Laspra Rodríguez has recently examined (2015), although the Roderick theme received a higher degree of attention, the presence of Pelayo is also a conspicuous one in some of the texts written by canonical authors such as Southey or Wordsworth. Southey portrays Pelayo as the hope of the Spanish nation in the aforementioned Roderick, the Last of the Goths (1814) and Wordsworth started the composition of a poem devoted to Pelayo after knowing about the French invasion of 1808. However, Wordsworth's poem, which starts "A few bold patriots, reliques of the fight", remained unfinished and, consequently, unpublished. Furthermore, the legend of Pelayo was extensively re-elaborated by other French, Italian, Portuguese, and North American writers in the Romantic period, as the studies edited by Coletes Blanco (2015) thoroughly explore. Therefore, Pelayo's presence in Don Juan; or the Battle of Tolosa is part of a transnational interest in Spain, its legendary past, and the connections that it may have with its present crisis.

\section{CONCLUSION}

As the preceding analysis reveals, Don Juan; or the Battle of Tolosa reconstructs a particular episode of the so-called reconquista by combining both history and romance. The anonymous author follows the traditional accounts of the battle and adopts a clearly pro-Christian attitude by portraying the conflict as a fight between the Spanish legitimate inhabitants of Iberia and the Moorish invaders. Although the poem participates in the Romantic vogue for SpanishMoorish themes and its interest in the decline of Al-Andalus, the author does certainly dissociate Muslim Iberia from the Spanish national identity. Moreover, 
the insistence on the recovery of the freedom of Spain and the emphasis on the heroic character of the Spanish people establish an implicit connection between the Battle of Las Navas de Tolosa and the campaigns of the Peninsular War. Hence, past and present, facts and fiction converge in this poem so as to perpetuate the Romantic image of Spain that prevailed in British print culture in the first decades of the nineteenth century.

\section{REFERENCES}

Almeida-Beveridge, J. 2010. Romanticism and the Anglo-Hispanic Imaginary. Amsterdam: Rodopi.

Alvira Cabrer, M. 2012. Las Navas de Tolosa. Idea, liturgia y memoria de una batalla. Madrid: Sílex.

Anon. 1815. De Mowbray. London: James Harper \& Co.

Anon. 1816. Don Juan; or the Battle of Tolosa. London: James Harper and Co.

Bigland, J. 1810. The History of Spain from the Earliest Period to the Close of the Year 1809. Vol. 1. London: Longman.

Byron, G. Gordon, Lord. 2008 (1812-1818). Childe Harold's Pilgrimage. Lord Byron: The Major Works. Ed. J. J. McGann. Oxford: Oxford University Press. 19-206.

Cayuela Fernández, J. G. and J. A. Gallego Palomares. 2008. La Guerra de la Independencia: Historia bélica, pueblo y nación en España (1808-1814). Salamanca: Universidad de Salamanca.

Coletes Blanco, A., ed. 2015. El Rey Pelayo en el Romanticismo europeo y norteamericano. Siete estudios críticos. Oviedo: Real Instituto de Estudios Asturianos.

Coletes Blanco, A. and A. Laspra Rodríguez, eds. 2013. Libertad frente a tiranía: poesía inglesa de la Guerra de la Independencia (1808-1814). Antología bilingüe. Barcelona: Espasa.

Curtis, M. 2009. Orientalism and Islam: European Thinkers on Oriental Despotism in the Middle East and India. Cambridge: Cambridge University Press.

Freire López, A. M. 2013. "Estrategias teatrales frente a la invasión francesa (18081814). El teatro patriótico durante la Guerra de la Independencia". Cuadernos de Ilustración y Romanticismo 19: 163-172.

Freire López, A. M. 2015. "Las reapariciones de Pelayo en el teatro español: la época de la invasión francesa". El Rey Pelayo en el Romanticismo europeo y norteamericano. Siete estudios críticos. Ed. A. Coletes Blanco. Oviedo: Real Instituto de Estudios Asturianos. 37-53. 
García Fitz, F. 2008. Las Navas de Tolosa. Barcelona: Ariel.

Grosrichard, A. 1998. The Sultan's Court: European Fantasies of the East. London, New York: Verso. Trans. L. Heron.

Iarocci, M. P. 2006. Properties of Modernity: Romantic Spain, Modern Europe, and the Legacies of Empire. Nashville: Vanderbilt University Press.

Iriarte, T. de. 1794. Lecciones instructivas sobre la historia y la geografía. Vol. 2. Madrid: Imprenta Real.

Kelly, R. N. 1815. The Inquisition, or, Tale of Varez: And Other Poems. London: James Harper \& Co.

Laspra Rodríguez, A. 2015. "Una segunda Reconquista: el Rey Pelayo y la Guerra de la Independencia en la literatura romántica británica”. El Rey Pelayo en el Romanticismo europeo y norteamericano. Siete estudios críticos. Ed. A. Coletes Blanco. Oviedo: Real Instituto de Estudios Asturianos. 163-199.

Lucena Giraldo, M. 2006. "Los estereotipos sobre la imagen de España". Norba: Revista de Historia 19: 219-229.

Rubiés, J. P. 2005. "Oriental Despotism and European Orientalism: Botero to Montesquieu”. Journal of Early Modern History 9 (1): 109-180.

Saglia, D. 1997. "The Exotic Politics of the Domestic: The Alhambra as Symbolic Place in British Romantic Poetry". Comparative Literature Studies 34 (3): 197 225.

Saglia, D. 1999. "Nationalist Texts and Counter-Texts: Southey's Roderick and the Dissensions of the Annotated Romance". Nineteenth-Century Literature 53 (4): 421-451.

Saglia, D. 2000. Poetic Castles in Spain. British Romanticism and Figurations of Iberia. Amsterdam: Rodopi.

Saglia. D. 2002. "The Moor's Last Sigh: Spanish Moorish Exoticism and the Gender of History in British Romantic Poetry". Journal of English Studies 3: 193-215.

Said, E. W. 1978. Orientalism. New York: Pantheon Books.

Sharafuddin, M. 1996. Islam and Romantic Orientalism: Literary Encounters with the Orient. London, New York: I. B. Tauris.

Singer, A. E. 1965. The Don Juan Theme, Versions and Criticism: A Bibliography. In West Virginia University Bulletin Series 66 (4-6). Online version at Don Juan Archiv Wien <http://www.donjuanarchiv.at/fileadmin/DJA/Forschung/ Don\%20Juan/Quellen\%20und\%20Texte\%20I/Bibliographie\%20Don-JuanFassungen/A.E.Singer/Bibliography\%20Don\%20Juan\%20Theme/Singer_1965. pdf $>$ (Accessed 17 February 2017) 
Tzoref-Ashkenazi, C. 2013. "Romantic Attitudes toward Oriental Despotism". The Journal of Modern History 85 (2): 280-320.

Valladares, S. 2012. "Walter Scott's Vision of Don Roderick (1811): A 'Drum and Trumpet Performance'?" Cuadernos de Ilustración y Romanticismo 18: 107-126.

Valladares, S. 2015. Staging the Peninsular War: English Theatre (1807-1815). Farnham: Ashgate.

Villegas-Aristizábal, L. 2015. "Norman and Anglo-Norman Intervention in the Iberian Wars of Reconquest before and after the First Crusade". Crusading and Pilgrimage in the Norman World. Eds. K. Hurlock and P. Oldfield. Woodbridge: The Boydell Press. 103-121.

Weinstein, L. 1959. The Metamorphoses of Don Juan. Stanford: Stanford University Press. 